\title{
"Today the Pot is Boiling Over!": Ebony Magazine, the Black Revolts, and the Search for a Social Resolution, 1966-1967
}

\section{Sid Ahmed Ziane}

\section{(2) OpenEdition}

\section{Journals}

Electronic version

URL: https://journals.openedition.org/ejas/16993

DOI: $10.4000 /$ ejas. 16993

ISSN: 1991-9336

\section{Publisher}

European Association for American Studies

\section{Electronic reference}

Sid Ahmed Ziane, "'Today the Pot is Boiling Over!": Ebony Magazine, the Black Revolts, and the Search for a Social Resolution, 1966-1967", European journal of American studies [Online], 16-2 | 2021, Online since 13 July 2021, connection on 17 October 2022. URL: http://journals.openedition.org/ejas/16993 ; DOI: https://doi.org/10.4000/ejas.16993

This text was automatically generated on 17 October 2022.

\section{(c) (1) (8)}

Creative Commons - Attribution-NonCommercial 4.0 International - CC BY-NC 4.0 https://creativecommons.org/licenses/by-nc/4.0/ 


\title{
"Today the Pot is Boiling Over!": Ebony Magazine, the Black Revolts, and the Search for a Social Resolution, 1966-1967
}

\author{
Sid Ahmed Ziane
}

1 In August 1967, Ebony published The Negro Youth, a special issue which explored the challenges that faced the Black youth in the ghettoes during the race riots. The special was a product of its time as it was run amidst a massive Black rebellion which swept the U.S. It was also distinctive in its approach as many Black and white outlets such McCall, the New York based and popular White-owned magazine admired its intellectual and empathic cachet, declaring that the special issues was, 'a brilliant example of writing and editing at its very best - penetrating, significant, and timely'. ${ }^{1}$

2 The special issue was also crucial from a different perspective. It propelled the National Advisory Commission on Civil Disorders, an 11-member commission established by President Lyndon B. Johnson to investigate the 1967 riots, to approach Ebony to procure some of its copies, believing that its writings were useful and could be used as references for their study to investigate the riots, their causes, and their consequences on the Black and White communities. Johnson and his editors happily rejoiced at the extent to which their magazine had become, 'tremendously effective'.

This article demonstrates how Ebony magazine distanced itself from the major Whiteoriented media, which was sensationalist in reference to the riots and often hostile to Black revolts and its exponents. In contrast to their approach, Ebony positioned itself as, 'a troubleshooting outlet' by making every effort to provide a set of resolutions to head off the Black revolts. 


\section{Literature Review:}

4 Scholarly studies on Ebony focused more broadly on its glamour while they neglected its critical side. In retrospect, conventional scholarship was taken up mostly by scholars of journalism such as Paul Hirsh, John Click, Gloria Myers, and A. V. Margavio who provided statistics on its editorial, advertising, and readership contents between 1945 and the early 1970s. Their studies revealed that Ebony had altered its editorial contents to reflect the shift in the readers' preferences as well as the Black social changes such as the emergence of Black identity or the rise of Black popular culture. ${ }^{3}$

Other scholars of journalism such as Michael Leslie added to this scholarship by focusing on how Ebony, as a leading Black glossy magazine in the U.S, promoted its advertising sector. In his 1995 study Slow Fade to?: Advertising in Ebony Magazine, Leslie argued that Ebony had increased its projection of a Black positive image and Black somatic models to respond to the Black is Beautiful movement of the 1960s. ${ }^{4}$

6 This scholarship was complemented by a recent trend led by other journalism scholars such as Jason Chambers, who shifted from statistics or content analyses of the magazine to focus on Johnson's career within the Black consumer market. Chambers explored how Johnson built a distinctive commercial power base within the Black publication field. In his 2008 study, Chambers argued that Johnson's pioneering success within the field of advertising and marketing, 'gave Johnson and his employees a level of authority in marketing and advertising to black consumers greater than that of any other black-owned company'. ${ }^{5}$ Chambers's study was a product of its time as it laid groundwork for future researchers to provide a complex understanding on the career and the social standing of Johnson and his editorial staff in post-war America.

7 Despite such efforts, Ebony's social standing during the modern Black liberation movement suffered a scholarly paucity. Traditional scholars such as Tony Atwater and Paul Hirsh sought to examine Ebony's policy toward the Civil Rights movement in the mid-1960s. Yet, their analysis is limited to major milestones in the Civil Rights movement such as the March on Washington and does not specifically engage with the intersection between Ebony and its relationship to the modern Black freedom movement. ${ }^{6}$

8 A new wave in this historiography led by historians and scholars of communication such as Korey Bowers Brown and E. James West began to address the political, social, and intellectual stand of Ebony in post-war America. Brown and West noticed how Ebony acted as an important forum by popularising the histories of Black Americans and addressing social issues such as the Vietnam Conflict and the urban riots. ${ }^{7}$ Such efforts provided a new avenue for scholars to situate Ebony within the social and historical context to explore its owner's and editors' social and intellectual debates in post-war America.

9 While the existing scholarship on Ebony has reached maturity, with a new wave of scholarly rethinking, Ebony's social standing in post-war America has not been addressed adequately. James West presents a more nuanced understanding on how Bennett helped to popularise and recover the history of Black Americans. Yet, West features Ebony as a serious historical outlet whereas this article argues that Ebony was also a critical outlet committed to addressing the social issues facing Black Americans. 
However, Brown's study chronicles how Ebony lived to its reputation during the Black Power era by addressing such social developments in Black America. Yet, the focus of his study pays a scant attention to how Ebony reacted to the Black revolts in the late 1960s. At the methodological level, Brown's study seems to rely heavily on Ebony's special sections (namely its Backstage and Letters to the Editors sections) whereas this article additionally scrutinises other important sections such as Photo-editorial, which provides comprehensive, detailed, and critical analysis on the Black revolts. Moreover, his study focuses almost entirely on Ebony's online issues while this study additionally uses archival and primary sources related to its owner and editorial staff, which do help to understand their critical engagement with the Black revolts. ${ }^{8}$

On the other hand, this article compares Ebony with other popular and regional White and Black-owned outlets. This is critical as it helps to position and assess Ebony's distinctiveness within the national print media and in relation to the Black revolts. Moreover, the popular and regional print media also ran significant stories on Ebony and did reveal the multifarious characteristics of the magazine, its publisher, and its editors.

Therefore, this article offers a unique contribution to the existing scholarship as it demonstrates that Ebony also proved itself to be more than a glossy magazine or a place for historical work, but also a critical outlet which situated itself at the heart of the racial unrest which plagued the U.S in the late 1960s. This article is important because it will develop a more complex understanding of how its owner and his editorial staff went beyond their commitment to mirror the happier side of the Black lives to reflect and address the social issues facing Black America in the post-war America.

13 Ultimately, this article will contribute to the most recent historiographical trend set by scholars of media such as Charles Simmons and Carl Senna. These scholars focused on a number of popular Black outlets as case studies and demonstrated how they played a vital role during the fight for justice and equality in post-war America. Yet, whilst this had laid important groundwork, there has not been adequate mention of Ebony. ${ }^{9}$

\section{The Rise of the Black Revolt:}

In the late 1960s, the Black Power movement reverberated throughout the nation, amplifying the philosophy of Black Radicalism and Nationalism and magnifying tactical differences between the popular Civil Rights moderators and the new Black Power advocates. Such dissensions were clearly perceived between the integrationist activist and the chief of the Southern Christian Leadership Conference (SCLC) Dr. Martin Luther King and Stokely Carmichael, the radical activist and the newly elected chairman of the Student Non-Violent Coordinating Committee (SNCC). The pair publicly disagreed with each other over their tactics to achieve liberation for Black Americans. ${ }^{10}$ While Dr. King often asserted that the struggle should be spearheaded by non-violent and integrationist approaches, Carmichael frequently declared that liberation could only be achieved by means of autonomy, self-help, and self-determination. ${ }^{11}$

These sharp disagreements had in fact precipitated a rupture in the mainstream of the modern Black freedom movement. In July 1966, the Congress of Racial Equality (CORE) declared its independence from the mainstream of the Civil Rights movement to embrace Black Power. ${ }^{12}$ Within the same month, Roy Wilkins of the National 
Association for the Advancement of Coloured People (NAACP) learned about CORE's metamorphosis into a full Black Power organisation and declared, during the NAACP's annual convention, that he would thoroughly reject Black Power, characterising it as racism in reverse: 'it was a "reverse Mississippi, a reverse Hitler, a reverse Ku Klux Klan', declared Wilkins. Wilkins later wrote for the NAACP's magazine The Crisis that the NAACP would eventually repudiate it: 'No matter how endlessly, the term "black power" means "anti-white power" [...] in a racially pluralistic society, the concept, [...] means opposition to other ethnic powers [...] We of the NAACP we will have none of this $[\ldots]^{13}$

Wilkins's and the NAACP's rejection of Black Power was further compounded when the leaders of the Civil Rights movement, among them Dr. King and the executive director of National Urban League (NUL) Whitney Young, signed what they called, 'the Crisis and Commitment'. This statement publicly announced their rejection of Black Power and called for unity by pursuing and reinforcing the integrationist and non-violent tactics. $^{14}$

The Black liberation struggle, which was at a cross-roads, also marked the rise of the Black Panther Party (the BPP). The BPP emerged as the most revolutionary and radical Black Power organization. The BPP was founded in Oakland, California, in October 1966 by the Meredith Collegians and the Louisianan African Americans Huey Percy Newton and Bobby Seale. Upon its foundation, the party, 'immediately incurred the decidedly violent and deadly wrath of all levels of government', taking its responsibility for the survival and the advancement of Black America and challenging, 'the white monopoly on violence in black communities'. ${ }^{15}$ As such, the BPP and its fight against police brutality, the threat it faced from federal and law enforcement institutions such as the FBI, the dissensions and the purges which occurred within the party, and its political connections with the Third World countries such as Cuba and China had brought the racial tension into a sharper focus. ${ }^{16}$

The fracture in the mainstream of the modern Black liberation movement was indeed coupled with a year of massive Black rebellion, which alerted the nation to a long and severe racial conflict. Indeed, 1967 saw one of the ugliest mass Black revolts in memory, as almost 200 riots plagued the major cities such as Detroit and Newark. Eighty-three people died, most of them Blacks, with 1,800 injured, and over $\$ 100$ million in property damage. ${ }^{17}$

factors influenced and fed directly and indirectly into the spark of the riots. Dr. King accused the U.S Congress for creating, 'atmosphere for these riots' due to its failure in enacting some social programs such as jobs programs or because of its implementation of, 'an economic cutbacks' in some Black neighbourhood. ${ }^{18}$ For many Black Americans, however, most of the riots erupted because of residential segregation and job disparities in the major cities. ${ }^{19}$ Historian Peter B. Levy argues that the eruption of the race riots in the 1960s could be attributed to the shortcomings of the Civil Rights movement as the Civil Rights of 1964 and the Voting Rights Act of 1965 did not radically, 'signify the fulfilment of the black freedom struggle'. ${ }^{20}$

President Lyndon B. Johnson quickly set up an 11-member commission to investigate the 1967 riots, headed by Illinois governor, Otto Kerner. The commission, called 'The National Advisory Commission on Civil Disorders' quickly released a detailed report, known as Kerner Report, which provided a clear explanation on the causes, consequences, and possible resolutions to quell these riots. The bulk of the report 
indicated that police practises, unemployment, and ghettoes or slum conditions were the key motives that sparked the riots. However, despite the report's possible resolutions to quell the riots, the panel concluded that, 'this is our basic conclusion: Our nation is moving toward two societies, one black, one white--separate and unequal. 21

The popular White print media fretted its concern over the civil disturbance, fearing that the latter would lead to a violent revolution that could sweep the entire country. The popular White daily newspaper The New York Times feared that the expansion and continuation of these riots would result in a nationwide backlash against White-Black relations. ${ }^{22}$ The Crisis magazine, however, grieved over the intensity and magnitude of the riots and hoped for a successful resolution whereas the regional and the Pennsylvanian newspaper The Tribune described the riots as, 'the gravest domestic crisis since the Civil War' and called for an immediate end to these violent acts. ${ }^{23}$

More tellingly, other popular White-owned newspapers and magazines cast Black Power advocates as, 'the catalyst of the national turmoil'. The Popular American newspaper The Washington Post blamed Rap Brown, the fifth chairman of the SNCC and Stokely Carmichael, among a few, for their sharp orientation in boiling up the Black rebellion. ${ }^{24}$ The American weekly news magazine Time, however, ascribed the eruption of the race riots to the rise of Black Power while the Detroit based newspaper Detroit Free Press attributed the spark of Detroit's riot to ideology of the Black militancy, announcing that the latter was, [...] the destructive philosophy which feeds on hate and incites violence $[. ..]{ }^{\prime} .{ }^{25}$

Perhaps the bloodiest racial unrest that occurred in 1967 was the Detroit riots, which recorded the worst racial bloodshed that had ever occurred in the history of America. The city turned into a battlefield: looting, vandalism, and ransacking rampaged the whole city. Every police officer and fireman were called to duty but were unable to control the situation. The devastating riot prompted Detroit governor George Romney to send in over 7,000 National Guard and U.S Army troops, who patrolled the city with tanks and armoured carriers to disperse the rioters. ${ }^{26}$

In many ways, the Detroit riot reflected the highest level of distress, bitterness, and anger among Black Americans, as was noted by The Washington Post, which depicted Detroit riot as, 'A Rage of Oppression', 'A bottle was thrown at police officers', put the newspaper, 'And just like that, Detroit exploded'. ${ }^{27}$ The New York Times described Detroit's riot, 'the worst civil strife in modern times as almost 1,400 buildings burned, over 7,200 people were arrested, 43 people died, 1,189 were injured, and about $\$ 50$ million in property damage. ${ }^{28}$

\section{"Today the Pot is Boiling Over!":}

Amidst such a national turmoil, Ebony, a glossy Black magazine owned by John $\mathrm{H}$. Johnson, a popular Black businessman and the owner of the Johnson Publishing Company (JPC), decided to step in to head off these unabated riots. Ebony sought to do so by suggesting a set of social resolutions to its Black and White audience. The social resolutions were introduced in the hopes of ending or at least blunting the racial tensions as well as eradicating the social issues such as poverty, slum conditions, joblessness, and homelessness. 
Black revolts, but also an apparent change in its tone, with statements which spoke directly and often sharply to White America. In October 1966, Ebony used this section to ask its White audience to imagine themselves being discriminated and harassed in the same way that the Black people experienced. Ebony declared that if they ever experienced such a situation, 'they would revolt almost immediately and there would be no talk of non-violence on their part'. ${ }^{35} \mathrm{E}$. Washington Rhodes, publisher of the popular Black-owned newspaper The Philadelphia Tribune, admired Ebony for its strong reaction while New York resident Louise Smith was impressed by Ebony's response, 'you have hit' said Smith, 'I am sure, the most critical issue of race relations to face us [...] ${ }^{36}$ December 1966, Ebony again published in its Photo-editorial a statement which questioned the purpose behind the U.S government interfering, "in other nations' problems while neglecting its domestic problems". Ebony angrily added that, "just as the federal government spends billions of Dollars on its space programs it must be prepared to spend billions on its race programs'. ${ }^{37}$ 
Ebony's editors also expressed their frustration over the U.S government's negligence of the social issues surrounding Black Americans, with its associate editor David Llorens denouncing the White Americans and the Black middle-class for turning their back on the Black ghettoes dwellers whereas its senior editor Lerone Bennett Jr. declaring that it was, 'the system' which led Black youth to revolt. ${ }^{38}$ Historian Korey Brown echoes these sentiments, emphasising that the Black youth revolted not only because they were lawless hoodlums, but because, 'too many Americans would rather turn a blindeye to the plight of the ghettos than to invest the time and resources needed to truly solve the problem. ${ }^{39}$

On the other hand, Ebony's critical characteristics prompted some White-owned periodicals such as Emporia Gazette to warn Johnson about redirecting his magazine toward a radical orientation. ${ }^{40}$ Yet, in contrast to its unfavourable comments, Johnson responded by declaring that, [...] I am not speaking for looters and burners, though I can understand them [...]. ${ }^{41}$ Therefore, Johnson was willing to venture upon pushing Ebony to address the current-riots situation, regardless of how the situation was or what was the White print media's reactions, 'We are committed to telling all of the story, the good and the bad [...]', declared Johnson. ${ }^{42}$

In fact, Ebony's serious endeavours to head off the revolts were sought even before the 1967 riots. At the end of 1966, Ebony revealed to its audience practical resolutions that they could exert to eradicate the revolts. Ebony stated that some programs such as slum clearance and neighbourhood rehabilitation should be worked out whereas education and job opportunities should be provided, developed, improved, and supported by the federal government with no partisan politics. However, it also noted that Black people and Civil Rights organisations should also take part in these programs by forming groups and holding meetings to study and address these racial problems. ${ }^{43}$

\section{'To Face the Battle Ahead', Ebony and "The Negro Youth":}

Ebony's determined attempt to quell the Black revolts expanded more broadly in the summer of 1967, with the magazine having announced the arrival of a special issue on the Black youth and the Black revolts, declaring that the issue would be dedicated, 'to understand the plight of the Negro youth in America [...] ${ }^{144}$ In fact, Ebony was aware that the Black revolts were attributable to the Black youngsters, as noted by its publisher Johnson, who declared that the Black youth provided, 'the original spark for the revolt'. ${ }^{45}$ Indeed, the National Advisory Commission on Civil Disorders found that most of the riots which were touched off in 1967 in the major cities were the direct outcome of the Black youngsters, as almost $53 \%$ of the arrestees aged between 15 and $24 .{ }^{46}$

The Negro Youth special issue, which was afoot to celebrate Ebony's third annual series of its special issues, was introduced in August 1966, drawing together an array of contributors, commentators, and editorial staff such as David Llorens and Phyl Garland, who provided critical statements and showed empathy with some Black youth and their experience during the riots. ${ }^{47}$ Florida Today newspaper declared that The Negro Youth was, 'the toughest issue in the magazine [...] ${ }^{148}$

Some contributors such as Alex Poinsett and Kenneth B. Clark argued that the rationale behind their revolts had stemmed from their suffering of racial inequities, lack of 
appropriate education, racial isolation, school segregation, and unemployment. ${ }^{49}$ These aspects forced Black youngsters to search for their Black identity in an effort to assert their manhood and their self-esteem and to show their, 'power to destroy [...] ability to rebel [...]' and willingness to, 'exposing oneself to danger [...] $]^{50}$

On the other hand, the special issue was drawn to search for a practical resolution to resolve the issue of the young Black rioters. In its special issue, Ebony proved to its youth readers their limitless potential to strive to reform their social lives as it provided abundant examples of Black youth who could successfully set up funding or rehabilitation programs for themselves or for other young Black Americans in some cities such as Watts and Chicago. ${ }^{51}$ In so doing, Ebony demonstrated to its young audience that they could single-handedly improve their own social conditions without rebelling, 'if you are a Negro youth growing up in a slum ghetto area [...]', said Ebony, 'there is a chance [...] without any major help from anyone, you will get education, go on to college, and become a productive, well-adjusted to the society. ${ }^{52}$

Relatedly, Ebony did not refrain from encouraging its youth audience to be determined to 'face the battle ahead' and struggle to improve their social lives. While it was a magazine with some inspirational tones, Ebony noted that their increasingly Black consciousness, their awareness of their past, and their pride of their race would eventually help them to seize ample opportunities to achieve liberation, compared to the previous decades, 'Negro Youth must take up the challenge [...] 'Poor schools are better than no school at all [...] Jobs paying minimum wages [...] are better than being unemployed', put Ebony. ${ }^{53}$

Combined with such an empathetic attention and a comprehensive analysis, the special issue proved to be very significant, with the Wisconsin White-owned newspaper Portage Daily Register admitting that the issue provided, 'a much more balanced, level-headed and factual analysis of the situation of the young Negro in America today'. ${ }^{54}$ However, the readers also admired the issue, acclaiming this veer and rejoiced at Ebony's focus on the cause of Black revolts. Pennsylvania resident Jacqueline A. Akins welcomed its critical tone and admitted that the magazine had timed it perfectly in its representation of the issues of Black America whereas Lawrence H. Janssen, director of Church Strategy Program in Pennsylvania, admired that the issue was of a great value that could even be published in a book, distributed for reading, or put in the library shelves. ${ }^{55}$

41 Perhaps the clearest evidence of its significance could be manifested in the governmental voices having approached the magazine to procure some of its copies, believing that the special could be used as a reference for their study to investigate the riots disorders. Indeed, Vice president Hubert H. Humphrey's office requested fifty copies of the special issue from Ebony to use it in the summer program across the country. Otto Kerner himself, who was appointed by President Lyndon B. Johnson to investigate the riots, also asked for copies from Ebony to use them for the same purpose. ${ }^{56}$ Even members of the commission used Ebony's special in their investigation and admitted that the special was, 'helpful in arriving at their conclusions ${ }^{57}$ Moreover, the distinctiveness of its special issue propelled the National Advisory Commission to invite Ebony's senior editor Lerone Bennett to take part in its close meetings on the civil disorder, believing that he was an expert who could deal with, 'historical, economic, sociological, and psychological factors of the ghettoes life'. ${ }^{58}$ 
42 As such, it is very clear how Ebony, its publisher, and its editors had an impact on the Black revolts, the Lyndon B. Johnson administration, and to a wider extent, the Black and the White audience. The Black print newspaper and the Chicago based South Side Bulleting admitted that at the time when the White press predicated on sensational stories and failed to improve the race relations, 'Ebony is forced to attempt a monumental task of filling the void [...] to be standing alone at the bulwarks of a national communications crisis'. ${ }^{59}$

\section{Conclusion:}

In April 1973, Rob Cuscaden, a journalist at the Chicago based The Sun Times newspaper, published a controversial article on the role of the Black media within the Black community. Whilst he admitted that the Black media was empathetic and honest in addressing the concerns of Black Americans, he declared that Ebony enjoyed a somewhat better reputation among the Black people because, 'it spoke about subjects of special interests, it used language that made sense to its own people, and it dealt seriously with important events' ${ }^{60}$ This declaration was emphasised by Johnson himself, who happily declared that his magazine had become very successful as it captured all segments of the Black lives, regardless of their orientations, 'the progress and the setbacks, the peaceful demonstrations and the riots, the middle of the readers and the black militants - all were reflected[...] ${ }^{61}$

Popular writers such as Brent Staples, editor for The New York Times, declared that Ebony had gone beyond its commitment to showcase the Black positive life to address how African-Americans perceived themselves in relationship to business, the arts, and the civil rights movement. ${ }^{62}$ Moreover, with such efforts, Ebony proved that it was a critical magazine with a relevant, significant, and distinctive approach. William I. Nichols, publisher of the popular White-owned magazine This Week magazine, admitted that Ebony was distinctively excellent in catching up the current situation in a discursive, argumentative way, thanking and venerating Johnson and his editorial staff, '[...] you have been successful' admitted Nichols, 'in making "the constructive side" seem interesting, exciting, and contagious"'. ${ }^{63}$

From a contrasting perspective, the insight of The Negro Youth also propelled Ebony to continue and intensify its quest for a social resolution to eradicate the Black revolts. Johnson and his editors declared that they would be committed to '[...] quietly resolve to keep trying [...]', they added, 'we will peer into complicated situations and make them understandable to the average man'. ${ }^{64}$ Ebony's sustained efforts to address the social issues which plagued Black America had pushed pivotal figures such as New York governor and future vice president of the U.S Nelson A. Rockefeller to admit that the magazine was indeed performing, 'a valuable service to every Negro community in the country $[. . .]^{6}{ }^{6}$

This article has argued that Ebony played a key role during the Black revolts by bringing a set of effective resolutions to head off the riots. Its successful intervention set a significant and useful benchmark within the American publication field. John H. Johnson proudly declared that his magazine had become an influential voice in America as its concerted efforts to resolve the racial issues had urged some governmental voices to approach the magazine and its editorial staff to cooperate with them..$^{66}$ 
Nonetheless, while this article has provided a critical analysis on Ebony's social standing during the racial unrest of the late 1960s, there remains much more to be said about Ebony's intervention during the Black revolts. Bennett's writings on the Black revolts in Ebony should deserve a scholarly rethinking as was seen by historian Korey Brown as, 'Ebony's most compelling commentaries' ${ }^{67}$ Other editors such as David Llorens and Allan Morrison and their engagement with the Black revolts outside the JPC can also offer a promising avenue to analyse the JPC's left-leaning editors' involvement in the Black ghettoes, and to wider extent, with the Black youth. Perhaps the release of the archival holdings of the JPC, which are currently being processed by the Smithsonian National Museum in Washington D.C and Getty Institute in Los Angeles, would aid historians to offer a more nuanced appraisal on Ebony's, its publisher's, and its editors' social standing in the post-war era.

\section{BIBLIOGRAPHY}

'A Challenge to Youth', Ebony, August 1967.

"As we see it, Collision of Subtle Forces Contributed to City's Riots", Detroit Free Press, 28 July 1967.

Atwater, Tony, "Editorial Policy of Ebony before and after the Civil Rights Act of 1964", Journalism Quarterly 01 (1982), 87-91.

Austin, Curtis J., Up Against the Wall, Violence in the Making and Unmaking of the Black Panther Party (Fayetteville, University of Arkansas Press, 2006).

"Backstage", Ebony, August 1967.

"Backstage", Ebony, March 1968.

"Backstage", Ebony, January 1970.

"Backstage", Ebony, January 1971.

"Backstage", Ebony, July 1967.

Bloom, Joshua and Martin Jr, Waldo E., Black against Empire: The History and Politics of the Black Panther Party (Berkeley, Calif: University of California Press, 2013).

Brown, DeNeen L., "In Detroit, 'the rage of oppression.' For five days in 1967, riots consumed a city"' (2020), https://www.washingtonpost.com/.

Brown, Korey Bowers, "SOULED OUT: Ebony Magazine in an Age of Black Power, 1965-1975", (Ph.D. Thesis, Howard University, 2010).

"Carmichael, Brown Show at Columbia: Carmichael, Brown Invade Columbia, Back Protesters", The Washington Post, 27 April 1968.

Chambers, Jason, Madison Avenue and the Color Line: African Americans in the Advertising Industry (Philadelphia: University of Pennsylvania Press, 2008).

Clark, Kenneth B., "The Search for Identity", Ebony, August 1967. 
Click, John W., "Comparison of Editorial Content of Ebony magazine, 1967 and 1974", Journalism Quarterly 52, no.4 (1975), 716-720.

"Congressional Investigation of Racial Riot is Proposed", The Tribune, 26 July 1967.

"Crisis and Commitment", The New York Times, 15 October 1966.

"Detroit Armed Camp", The Windsor Star, 24 July 1967.

"Ebony Changes Style", Emporia Gazette, 26 March 1968.

"Ebony", Florida Today, 01 December 1968.

"Ebony Mag Points to 'Positivism", South Side Bulletin, 7 August 1968.

Ellis, Eddie, "Is Ebony a Negro Magazine", Liberator, October 1965.

"Father Groppi is Negative", Portage Daily Register, 2 September 1967.

Garland, Phyl, "The Gang Phenomenon: Big City Headache", Ebony, August 1967.

Goodman, Walter, "Ebony, The Black Man's Life", Florida Today, 1 December 1968.

Hall, Simon, "The NAACP, Black Power, and the African American Freedom Struggle, 19661969", The Historian 69, no.1, (2007), 49-82.

Harry Haywood, "Is the Black Bourgeoisie the Leader of the Black Liberation Movement?

", Soulbook, 01, no.1 (Summer 1966), 01-81.

"HHH, Riots Study Penal Get Ebony Special Edition", Jet, 24 August 1967.

Hirsh, Paul M., "An Analysis of Ebony: The Magazine and Its Readers", Journalism Quarterly 45, no. 2 (1968), 261-292.

"How Long, Oh Lord, How Long?", Ebony, September 1967.

Hoyt Fuller Papers, Clark Atlanta University, Robert W. Woodruff Library, Special Collections, Atlanta. GA

John H. Johnson, "Ebony Magazine: On Turning 30", The Washington Post, 21 November 1975.

John H. Johnson, John H., "Publisher statement", Ebony, August 1967.

Johnson, John. H, with Bennett Lerone Jr., Succeeding against the Odds, the Autobiography of a Great American Businessman (New York: Amistad Press, 1989).

Joseph, Peniel E., Stokely: A Life (New York: Civitas Books, 2016).

Joseph, Peniel E., Waiting 'Til the Midnight Hour (New York: Henry Holt and Company, LLC, 2006). Ingham, John N and Feldman, Lynne B., Contemporary American Business Leaders: A Biographical Dictionary (London: Greenwood Press, 1990).

Lerone Bennett, Jr. papers, Stuart A. Rose Manuscript, Archives, and Rare Book Library, Emory University. GA

Leslie, Michael, "Slow Fade to?: Advertising in Ebony Magazine, 1957-1989", Journalism \&Mass Communication Quarterly 72, no.2 (1995), 426-435.

Levy, Peter B., The Great Uprising Race Riots in Urban America during the 1960s (Pennsylvania: Cambridge University Press, 2018).

Loessberg, Rick, "Two Societies: The Writing of the Summary of the Report of the National Advisory Commission on Civil Disorders", Journal of Urban History 44, no.6 (2017), 1039-1061. 
Myers, Gloria and Margavio, A.V, "The Black Bourgeoisie and Reference Group Change: A Content Analysis of Ebony", Qualitative Sociology 6, no.6 (1983), 291-307.

Olzak, Susan and Shanahan, Suzanne, "Deprivation and Race Riots: An Extension of Spilerman's Analysis", Social Forces 74, no.03 (1996), 931-961.

Olzak, Susan et al, "Poverty, Segregation, and Race Riots: 1960 to 1993", American Sociological Review 61, no.04 (1996), 590-613.

"Letters to the Editors", Ebony, December 1966.

"Letters to the Editors", November, Ebony 1966.

"Letters to the Editors", Ebony, November 1967.

"Letters to the Editors", Ebony, November 1966.

"Letters to the Editors", Ebony, November 1967.

"Letters to the Editors", Ebony, October 1967.

Llorens, David, 'Apostle of Economics', Ebony, August 1967.

National advisory of Civil Disorder, 06, http://www.eisenhowerfoundation.org/docs/kerner.pdf "Opportunity Please Knock", Ebony, August 1967.

Poinsett, Alex, "Ghetto School, an Educational Wasteland", Ebony, August 1967.

"Races: The Jungle and the City", Time, July 29, 1966.

"Request for a Riot Cure", Ebony, December 1966.

Sanders, Stanley, "I'll Never Escape the Ghetto", Ebony, August 1967.

Senna, Carl, The Black Press and the Struggle for Civil Rights (New York: Franklin Watts, 1993).

Simmons, Charles, African American Press: A History of News Coverage During National Crises (North Carolina: McFarland \& Company, 2006).

Staples, Brent, "The Radical Blackness of Ebony Magazine", accessed 11 July 2020, https:// www.nytimes.com/.

"Sheriff Tells of Cost", The New York Times, 16 August 1967.

Spencer, Robin C., The Revolution Has Come, Black Power, Gender, and the Black Panther Party in Oakland (Durham: Duke University Press, 2016).

"The Backlash: After Progress and Riots Protest at the Polls", The New York Times, 02 Oct 1966.

"The Civil Rights Movement in America: From Black Nationalism to the Women's Political Council", ed. by Peter B. Levy (Santa Barbara: Greenwood, 2015).

The Editorial, "The Grim Hot Summer of 1967", The Crisis, Aug-Sep 1967.

"The Negro Youth", Ebony, August 1967.

"The Rights of Man", Ebony, October 1966.

"U.S. Probing Carmichael's Role in Riot", The Washington Post, 12 April 1968.

Walsh, Kenneth T., "50 Years After Race Riots, Issues Remain the Same", 4 February 2021, https:// www.usnews.com/.

West, E. James, Ebony Magazine and Lerone Bennett Jr. Popular History in Post War America (Urbana: University of Illinois Press, 2020). 
White, William S., "Long Hot Summer...: Repeated Cliché Seen as Blackmail", The Washington Post, 23 May 1967.

Wilkins, Roy, "Whiter "Black Power", The Crisis, Aug-Sep 1966.

\section{NOTES}

1. See, 'The Negro Youth', Ebony, August 1967; 'Letters to the Editors', Ebony, November 1967, 22.

2. 'Backstage', Ebony, March 1968, 26.

3. John W. Click, 'Comparison of Editorial Content of Ebony magazine, 1967 and 1974', Journalism Quarterly 52 (1975), 716-720; Paul M. Hirsh, ‘An Analysis of Ebony: The Magazine and Its Readers', Journalism Quarterly 45 (1968), 261-292 (265); Gloria Myers and A.V Margavio, 'The Black Bourgeoisie and Reference Group Change: A Content Analysis of Ebony', Qualitative Sociology 6 (1983), 291-307.

4. Michael Leslie, 'Slow Fade to?: Advertising in Ebony Magazine, 1957-1989', Journalism \&Mass Communication Quarterly 72 (1995), 426-435.

5. Jason Chambers, Madison Avenue and the Color Line: African Americans in the Advertising Industry (Philadelphia: University of Pennsylvania Press, 2008), 43.

6. Tony Atwater 'Editorial Policy of Ebony before and after the Civil Rights Act of 1964', Journalism Quarterly 01 (1982), 87-91, Paul Hirsh, An Analysis of Ebony, Ibid.

7. Korey Bowers Brown, "SOULED OUT: Ebony Magazine in an Age of Black Power, 1965-1975", (Ph.D. Thesis, Howard University, 2010); E. James West, Ebony Magazine and Lerone Bennett Jr. Popular History in Post War America (Urbana: University of Illinois Press, 2020).

8. Korey Bowers Brown, SOULED OUT, Ibid.

9. Charles Simmons, African American Press: A History of News Coverage During National Crises (North Carolina: McFarland \& Company, 2006); Carl Senna; The Black Press and the Struggle for Civil Rights (New York: Franklin Watts, 1993).

10. Peniel E. Joseph, Waiting 'Til the Midnight Hour (New York: Henry Holt and Company, LLC, 2006), 136-138; Peniel E. Joseph, Stokely: A Life (New York: Civitas Books, 2016), 152-153

11. Joseph, Waiting, Ibid, 143.

12. Roy Wilkins, "Whiter "Black Power"", The Crisis, Aug-Sep 1966, 354; Simon Hall, 'The NAACP, Black Power, and the African American Freedom Struggle, 1966-1969', The Historian 69 (2007), 49-82 (58).

13. Roy Wilkins, "Whiter "Black Power"", Ibid, 354; Simon Hall, The NAACP, Black Power, and the African American Freedom Struggle, Ibid.

14. "Crisis and Commitment", The New York Times, 15 October 1966, 206; Joseph, Stokely, Ibid, 153.

15. Curtis J. Austin, Up Against the Wall, Violence in the Making and Unmaking of the Black Panther Party (Fayetteville, University of Arkansas Press, 2006), 20.

16. See for example: Joshua Bloom and Waldo E. Martin Jr, Black against Empire: the History and Politics of the Black Panther Party (Berkeley, Calif: University of California Press, 2013); Curtis J. Austin, Up Against the Wall, Violence in the Making and Unmaking of 
the Black Panther Party (Fayetteville, University of Arkansas Press, 2006); Robin C. Spencer, The Revolution Has Come, Black Power, Gender, and the Black Panther Party in Oakland (Durham: Duke University Press, 2016).

17. Kenneth T. Walsh, '50 Years After Race Riots, Issues Remain the Same', 4 February 2021, https://www.usnews.com/.

18. King/SCLC, Bennett papers, box 2, Lerone Bennett, Jr. papers, Stuart A. Rose Manuscript, Archives, and Rare Book Library, Emory University.

19. Susan Olzak et al, 'Poverty, Segregation, and Race Riots: 1960 to 1993', American Sociological Review 61 (1996), 590-613; Susan Olzak, Suzanne Shanahan, 'Deprivation and Race Riots: An Extension of Spilerman's Analysis', Social Forces 74 (1996), 931-961.

20. Peter B. Levy, The Great Uprising Race Riots in Urban America during the $1960 \mathrm{~s}$ (Pennsylvania: Cambridge University Press, 2018), 02.

21. The Civil Rights Movement in America: From Black Nationalism to the Women's Political Council , ed. by Peter B. Levy (Santa Barbara: Greenwood, 2015), 188; Rick Loessberg, 'Two Societies: The Writing of the Summary of the Report of the National Advisory Commission on Civil Disorders', Journal of Urban History 44 (2017), 1039-1061 (p. 1039).

22. 'The Backlash: After Progress and Riots Protest at the Polls', The New York Times, 02 Oct 1966, 203.

23. The Editorial, 'The Grim Hot Summer of 1967', The Crisis, Aug-Sep 1967, 334-335; 'Congressional Investigation of Racial Riot is Proposed', The Tribune, 26 July 1967, 02.

24. 'Carmichael, Brown Show At Columbia: Carmichael, Brown Invade Columbia, Back Protesters', The Washington Post, 27 April 1968, 01; William S. White, 'Long Hot Summer...: Repeated Cliché Seen as Blackmail', The Washington Post, 23 May 1967, 17; 'U.S. Probing Carmichael's Role in Riot', The Washington Post, 12 April 1968, 01.

25. 'Races: The Jungle and the City', Time, July 29, 1966, 11; 'As we see it, Collision of Subtle Forces Contributed to City's Riots', Detroit Free Press, 28 July 1967, 06.

26. 'Detroit Armed Camp', The Windsor Star, 24 July 1967, 01.

27. DeNeen L. Brown, 'In Detroit, 'the rage of oppression.' For five days in 1967, riots consumed a city"' (2020), https://www.washingtonpost.com/.

28. 'Sheriff Tells of Cost', The New York Times, 16 August 1967, 27; DeNeen L. Brown, In Detroit, Ibid; Kenneth T. Walsh, '50 Years After Race Riots, Issues Remain the Same', Ibid.

29. 'How Long, Oh Lord, How Long?', Ebony, September 1967, 106.

30. , 'Ebony', Florida Today, 01 December 1968, 04.

31. Harry Haywood, 'Is the Black Bourgeoisie the Leader of the Black Liberation Movement?', Soulbook, 01 (Summer 1966), 01-81 (71-72); Eddie Ellis, 'Is Ebony a Negro Magazine', Liberator, October, 1965, 04-05.

32. 'Ebony', Florida Today, Ibid.

33. John H. Johnson with Lerone Bennett Jr., Succeeding against the Odds, the Autobiography of a Great American Businessman (New York: Amistad Press, 1989), 156-157; John N Ingham \& Lynne B. Feldman, Contemporary American Business Leaders: A Biographical Dictionary (London: Greenwood Press, 1990), 377.

34. 'Request for a Riot Cure', Ebony, December 1966, 144.

35. 'The Rights of Man', Ebony, October 1966, 142. 
36. 'Letters to the editors', Ebony, December 1966, 13; 'Letters to the editors', November, Ebony 1966, 18.

37. Ibid.

38. David Llorens, Titles, Labels, or People? In Search of Commitment, box 22, folder 5 , Hoyt Fuller Papers, Clark Atlanta University, Robert W. Woodruff Library, Special Collections, Atlanta. GA; Lerone Bennett Jr, Interview, box 7, Lerone Bennett, Jr. papers.

39. Korey Brown, SOULED OUT, Ibid, p. 140.

40. 'Ebony Changes Style', Emporia Gazette, 26 March 1968, 04.

41. Jason Chambers, Madison Avenue, 62, Ibid.

42. John H. Johnson, 'Ebony Magazine: On Turning 30', The Washington Post, 21 November 1975, p.A19.

43. Ibid; 'Request for a Riot Cure', Ebony, December 1966, 144.

44. 'Backstage', Ebony, July 1967, 25; 'Backstage', Ebony, August 1967, 19.

45. John H. Johnson, 'Publisher statement', Ebony, August 1967, 21.

46. National advisory of Civil Disorder, 06, http://www.eisenhowerfoundation.org/ docs/kerner.pdf

47. Phyl Garland, 'The Gang Phenomenon: Big City Headache', Ebony, August 1967, 96-103; David Llorens, 'Apostle of Economics', Ebony, August 1967, 78-86; Stanley Sanders, 'I'll Never Escape the Ghetto', Ebony, August 1967, 30-36.

48. Walter Goodman, 'Ebony, The Black Man's Life', Florida Today, 1 December 1968, p. 04E.

49. Alex Poinsett, 'Ghetto School, an Educational Wasteland', Ebony, August 1967, 52-57; Kenneth B. Clark, 'The Search for Identity', Ebony, August 1967, 39-42.

50. Alex Poinsett, 'Ghetto School, an Educational Wasteland', Ibid, 42.

51. Stanley Sanders, 'I'll Never Escape the Ghetto", Ibid; David Llorens, "Apostle of Economics', Ibid; Ebony, August 1967, 78-86; , 'Opportunity Please Knock', Ebony, August 1967, 104-107.

52. 'A Challenge to Youth', Ebony, August 1967, 144.

53. Ibid.

54. 'Father Groppi is Negative', Portage Daily Register, 2 September 1967, 02.

55. 'Letters to the Editors', Ebony, October 1967, 15-16.

56. 'HHH, Riots Study Penal Get Ebony Special Edition', Jet, 24 August 1967, 20-21.

57. 'Backstage', Ebony, March 1968, 26.

58. The National Advisory Commission on Civil Disorder to Bennett, 11 September 1967, Kerner report 67-8, Box 6, Lerone Bennett, Jr. papers, Stuart A. Rose Manuscript, Archives, and Rare Book Library, Emory University.

59. 'Ebony Mag Points to 'Positivism', South Side Bulletin, 7 August 1968, 09.

60. Rob Cuscaden, Ebony Surveys the Market, Hoyt Fuller Collection, box 21, folder 19.

61. 'Backstage', Ebony, January 1970, 25.

62. Brent Staples, "The Radical Blackness of Ebony Magazine", accessed 11 July 2020, https://www.nytimes.com/.

63. 'Letters to the Editors', Ebony, November 1967, 22. 
64. 'Backstage', Ebony, January 1971, 24.

65. 'Letters to the Editors', Ebony, November 1966, p.17.

66. Committee on Post Office and Civil Service, Hearings, Ibid, 395.

67. Korey Brown, SOULED OUT, Ibid, p. 140.

\section{ABSTRACTS}

This paper argues for Ebony's effective intervention during the Black revolts that swept the U.S between 1966 and 1967. While Ebony was a glossy magazine designed for promoting Black fashion, advertising, and consumerism, it also proved to be a critical outlet aiming at bringing about a social reformation to Black America. At the time when the popular and the regional white and Black-owned media did not provide a practical resolution to the race riots whilst others generated instances of sensationalism to vilify the Black revolt, Ebony appeared as a sui generis magazine by providing viable social resolutions to quell the Black revolts and the social problems impinging upon Black Americans. This intervention was culminated in a special issue which critically addressed the Black youth and their rationale behind sparking off the revolts. Its intervention, however, paid off, with the National Advisory Commission on Civil Disorders approaching the magazine to procure copies to use them on its investigation of the riots while inviting its senior editor Lerone Bennett Jr. to participate in its close meetings on the civil disorder. Based on archival materials as well as Ebony's special issues, this article sheds new light on Ebony's social standing in Post-war America.

\section{INDEX}

Keywords: Black Revolt, Social Resolution, Popular/Regional American print media, Ebony magazine

\section{AUTHOR}

\section{SID AHMED ZIANE}

I am a Ph.D. student at Manchester Metropolitan University. I study African American history and my area of interest revolves around race and media in Post-war America. I am particularly interested in the correlation between the modern Black print media and the modern Black liberation movement in the U.S. I am also interested in other themes related to the social movements in the U.S, American history, and cultural history. 